\section{Comparison of chloroxylenol $4.8 \%$ and povidone iodine $7.5 \%$ on total bacteria count post WHO routine hand washing on clinical students at the Department of Oral Surgery, Faculty of Dentistry, Universitas Sumatera Utara March-May 2018}

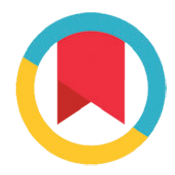

CrossMark

\author{
Ahyar Riza, ${ }^{*}$ Isnandar, Rahmi Syaflida, Jasmine
}

\begin{abstract}
:
Objective: To compare Chloroxylenol $4.8 \%$ and Povidone lodine $7.5 \%$ on total bacterial count post WHO routine hand washing on clinical students at the department of oral surgery, Faculty of Dentistry, Universitas Sumatera Utara

Material and Methods: This was an experimental study with posttest only control group design approach. Purposive technique is applied to collect samples which are clinical students. In this study, sample were divided into 3 groups and each consisting of 10 people. Aquadest was used as control group while Chloroxylenol $4.8 \%$ and Povidone lodine $7.5 \%$ was used as the treatment group. Each member
\end{abstract}

performed routine handwashing using WHO method for 1 minute long.

Results: The results were statistically analyzed using Kruskal Wallis and Mann-Whitney Test. The comparison between Chloroxylenol and Povidone lodine showed no significant difference to the total bacteria count after handwashing ( $p>0.05)$ but the Chloroxylenol group showed a greater mean reduction.

Conclusion: Chloroxylenol and Povidone lodine are capable reducing the number of bacteria in hands, therefore it can be a good antiseptic choice for hand washing.
Department of Oral and Maxillofacial Surgery, Faculty of Dentistry, Universitas Sumatera Utara, Medan, Indonesia
*Correspondence to: Ahyar Riza, Department of Oral and Maxillofacial Surgery, Faculty of Dentistry, Universitas Sumatera Utara, Medan, Indonesia ahyar.riza@usu.ac.id

Received: 1 February 2019 Revised: 12 May 2019 Accepted: 15 August 2019 Available Online 1 December 2019

Keyword: Handwashing, Chloroxylenol, Povidone lodine

Cite this Article: Riza A, Isnandar, Syaflida R, Jasmine. 2019. Comparison of chloroxylenol 4.8\% and povidone iodine 7.5\% on total bacteria count post WHO routine hand washing on clinical students at the Department of Oral Surgery, Faculty of Dentistry, Universitas Sumatera Utara March-May 2018. Journal of Dentomaxillofacial Science 4(3): 142-144. D0I: 10.15562/jdmfs.v4i3.796

\section{Introduction}

Maintaining hand hygiene is as important as taking care of our health. In daily activities, hands are often contaminated with microbes as it constantly in contact with the environment. ${ }^{1}$ In other words, hands are one of the media for entry of microbes into the body. The generally accepted ways to maintain hand hygiene is by hand washing. ${ }^{2}$ Hand washing is a simple activity that aims to remove dirt and minimize the number of germs in the hands and palms by using water and an additional substance, where the substance can be antiseptic. . $^{3,4}$

Study showed that hand washing can reduce germs by $58 \%$ in the palms. The reduction numbers of germs showed a close relationship to the improvement of individual health. ${ }^{5}$ Hand washing with soap has the potential to reduce diarrhea by 42 to $47 \%$. ${ }^{4}$ From a study conducted by Dorson, he stated that hand washing can reduce one million deaths per year caused by diarrhea. ${ }^{5}$

There are various types of hand washing agents such as plain soap, antiseptics and hand-sanitizers. Chloroxylenol and Povidone Iodine are one of the most common antiseptic agents and widely used in the medical and dental fields. Both of these ingredients work by damaging the bacterial cell wall, hence reducing the activity and number of bacteria. ${ }^{6}$

\section{Material and Methods}

This is an experimental study with post-test only control group design approach. The non probability sampling with purposive technique is applied to collect samples which are clinical students at Department of Oral and Maxillofacial Surgery in Faculty of Dentistry, Universitas Sumatera Utara. In this study, sample were divided into 3 groups and each consist of 10 people. Aquadest was used as control group while Chloroxylenol 4.8\% (Dettol) and Povidone Iodine $7.5 \%$ (Betadine Surgical Scrub) were used as the treatment group. The following procedure begins with $\mathrm{WHO}$ hand washing method by using aquadest for 1 minute and the following hand washing procedure is repeated by using the antiseptic agent. Hands were gently dried by using paper towel and soaked in a container that contain $\mathrm{NaCl}$ 0.9\% solution for 1 minute. Samples were then sent to the microbiology laboratory for bacterial cultivation on the plate count agar and 
incubated for 48 hours. The number of bacterial colonies grown were then counted. Data processing was done with computer analyzed using KruskalWallis and Mann-Whitney test.

\section{Results}

The mean result obtained for control group aquadest was $308.7 \pm 171.73 \mathrm{CFU} / \mathrm{mL}$, for treatment group Chloroxylenol was $23.6 \pm 58.63 \mathrm{CFU} / \mathrm{mL}$ and Povidone Iodine was $23.6 \pm 58.63 \mathrm{CFU} / \mathrm{mL}$. Table 1 .

The statistic test between the three groups were analyzed using Kruskal-Wallis test and the $\mathrm{p}$ value $=0.003<0.05$. Table 2 This results showed that there was a significant differences in the number of bacterial colonies between the aquadest, chloroxylenol and povidone Iodine.

Further test between two groups were analyzed using Mann-Whitney test. Between chloroxylenol and povidone Iodine group the $\mathrm{p}$ value $=0.116>0.05$,

Table 1 Total bacterial count after handwashing

\begin{tabular}{lccc}
\hline & \multicolumn{3}{c}{ Total Bacterial count (10 } \\
\cline { 2 - 4 } No & CFU/mL) \\
\hline 1 & Aquadest & $\begin{array}{c}\text { Chloroxylenol } \\
\mathbf{4 . 8} \%\end{array}$ & $\begin{array}{c}\text { Povidone lodine } \\
\mathbf{7 . 5 \%}\end{array}$ \\
2 & 350 & 0 & 0 \\
3 & 302 & 0 & 0 \\
4 & 455 & 0 & 30 \\
5 & 0 & 188 & 0 \\
6 & 335 & 0 & 0 \\
7 & 430 & 0 & 191 \\
8 & 365 & 0 & 170 \\
9 & 480 & 0 & 114 \\
10 & 0 & 21 & 75 \\
Total & 370 & 27 & 80 \\
Mean \pm Standard & 3087 & 236 & 660 \\
Deviation & $308.7 \pm 171$ & $23.6 \pm 58$ & $66 \pm 72$ \\
\hline
\end{tabular}

Table 2 Data analysis using Kruskal-Wallis test

\begin{tabular}{lc}
\hline Group & P-Value (Kruskal-Wallis) \\
\hline Aquadest & \\
Chloroxylenol $4.8 \%$ & 0,003 \\
Povidone Iodine $7.5 \%$ & \\
\hline
\end{tabular}

Table 3 Data analysis using Mann-Whitney test

\begin{tabular}{lc}
\hline Group & P Value (Mann-Whitney) \\
\hline Chloroxylenol 4.8\% and Povidone Iodine 7.5\% & 0,116 \\
Aquadest and Chloroxylenol 4.8\% & 0,003 \\
Aquadest and Povidone Iodine 7.5\% & 0.009 \\
\hline
\end{tabular}

while aquadest and chloroxylenol the $\mathrm{p}$ value $=$ $0.003<0.05$ and between aquadest and povidone Iodine the $\mathrm{p}$ value $=0.009<0.05$. Table 3 .

Data analysis using Mann-Whitney test with a significance level of $p<0.05$, and the conclusions are: there is no significant difference in the number of bacterial colonies between Chloroxylenol 4.8\% and Povidone Iodine $7.5 \%$ in routine hand washing, there is a significant difference in the number of bacterial colonies between Chloroxylenol $4.8 \%$ and the control group aquadest on routine hand washing, there is a significant difference in the number of bacterial colonies between Povidone Iodine 7.5\% and the control group aquadest on routine hand washing.

\section{Discussion}

Based on the results of the study, Chloroxylenol and Povidone Iodine were known to be more effective than aquadest in reducing the bacterial colonies after routine hand washing. While water is often called a universal solvent, it cannot directly remove hydrophobic substances such as fat and oil which often present on soiled hands. Proper handwashing therefore requires the use of soaps and detergent to dissolve fatty materials, thus water alone is not suitable for cleaning soiled hands. ${ }^{6}$

Things to be taken a notice on control group where there was no bacterial growth on 4th and 9th aquadest sample. This may be due to bacterial cultivation factors where the solution were not stirred beforehand which make the solution inhomogeneous hence none of the bacteria grow. ${ }^{7}$

The comparison number for bacterial colonies between Chloroxylenol and Povidone Iodine after routine hand washing showed an insignificant difference statistically. This can be due to the mechanism of action of the two agents which reduce the number of bacteria by damaging the cell wall and bacterial cell membrane. ${ }^{6,8,9}$

Chloroxylenol is a membrane active agent that are absorbed into the bacterial cell, and depending on the quantity absorbed results in growth inhibition or loss of viability. The antimicrobial activity of Chloroxylenol is minimaly affected by the presence of organic matter, but is neutralized by non-ionic surfactant. Bactericidal activity results from rapid disruption of the membrane structure and function and the general loss of cytoplasmic constituents from the cell. This membrane damage is irreversible and the cell is thus unable to overcome the loss of essential metabolites. The cytoplamic membrane and its components are considered to be the main sites of action of chlorinated phenol. ${ }^{6,9}$

The results from the 4 th Chloroxylenol sample group was $188 \mathrm{CFU} / \mathrm{mL}$ where this value is much 
greater than the 9th and 10th samples, which were 21 and $27 \mathrm{CFU} / \mathrm{mL}$. This may be caused by the respondent perform the WHO hand washing procedure incorrectly. Moreover, it could be caused by biological contamination during bacterial cultivation in laboratory. ${ }^{10,11}$

Iodine molecules rapidly penetrate the cell wall of microorganisms and inactivate cells by forming complexes with amino acids and unsaturated fatty acids, resulting in impaired protein synthesis and alteration of cell membranes. The amount of molecular iodine present (known as free iodine) determines the level of antimicrobial activity of iodophors. ${ }^{6}$ Although statistically the chloroxylenol and Povidone Iodine showed insignificant differences, the average results showed a lower bacterial reduction in the Povidone Iodine group. This can be caused by the antimicrobial activity of iodophors that affected by $\mathrm{pH}$, temperature, exposure time, concentration of total available iodine and the amount and type of organic (blood, sputum) and inorganic compounds presents (e.g. alcohols and detergents) ${ }^{6}$

\section{Conclusion}

From the results of the discussion above, it can be concluded that water is an universal solvent and hand washing with only water is not effective to clean dirty hands. Chloroxylenol and Povidone Iodine are capable at reducing the number of bacteria in hands, therefore it can be a good antiseptic choice for routine hand washing.

\section{Acknowledgment}

I would like to thank all the Lecturer Department of Oral and Maxillofacial Surgery, Ahyar Riza, Isnandar and Rahmi Syaflida for guiding and helping me until the completion of this article

\section{Conflict of Interest}

The authors report no conflict of interest.

\section{References}

1. Rhoades J, Gialagkolidou K, Gogou M. Oregano essential oil as an antimicrobial additive to detergent for hand washing and food contact surface cleaning. J App Microbiol 2013;115: 987-994.

2. Desiyanto FA, Djannah SN. Efektivitas mencuci tangan menggunakan cairan pembersih tangan (hand sanitizer) terhadap jumlah angka kuman. Kesmas 2013;7: 75.

3. Soedarmo SS, Gama H, Hadinegoro SR. Buku ajar infeksi dan pediatri tropis. 2nd ed. Jakarta: Ikatan Dokter Anak Indonesia; 2008: 1-5.

4. Curtis V, Cairncross S. Effect of washing hands with soap on diarrhea risk in the community: A systematic review. Lancet Infect Dis. 2003;3: 275-281.

5. Rachmawati FJ, Triyana SY. Perbandingan angka kuman pada cuci tangan dengan beberapa standarisasi pembersih tangan di lab mikrobiologi. Logika 2008: 6-7.

6. Nicolay CR. Hand hygiene: An evidence-based review for surgeons. Int J Surg 2006;4: 53-65.

7. Montville R, Schaffner DW. A meta-analysis of the published literature on the effectiveness of antimicrobial soaps. J Food Prot 2011;74: 1880-1881.

8. Fluent MT. Hand hygiene in the dental setting reducing the risk of infection. Compendium 2013;33: 1-4.

9. Hamuel JD. Effect of Dettol on viability of some microorganisms associated with nosocomial infections. African J Biotechnol 2008;7: 1561.

10. Montville R, Schaffner DW. A meta-analysis of the published literature on the effectiveness of antimicrobial soaps. J Food Prot Prot 2011;74: 1880-1881.

11. Riza A, Oes A, Rusdy H, Nisah K. Comparison of the effectivity of handrubbing and handwashing on the number of bacterial colonization on clinical students at the Department of Oral and Maxillofacial Surgery, Faculty of Dentistry, Universitas Sumatera Utara March-May 2018. J Dentomaxillofac Sci 2019;4: 105-108.

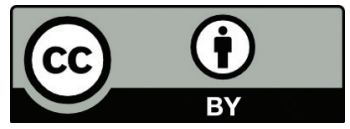

This work is licensed under a Creative Commons Attribution 